\title{
Stimulatory effect of pancreozymin-cholecystokinin on calcium secretion in pancreatic juice of $\operatorname{dogs}^{2,3}$
}

\author{
H. GOEBELL1, Ch. STEFFEN, AND Ch. BODE \\ From the Department of Medicine, Philipps-Universität, Marburg/Lahn, Germany
}

SUMmARY In four dogs with a permanent duodenal Thomas fistula the secretion of calcium, sodium, potassium, protein, and two pancreatic enzymes in pancreatic juice was studied. Infusion of secretin led to a decrease in concentration of calcium and of protein with increasing rates of fluid production. Pancreozymin-cholecystokinin was given in single injections superimposed on the secretin-stimulated flow of juice. This hormone stimulated the secretion of both calcium and enzyme protein in a parallel and closely correlated fashion. The secretion of this protein-bound calcium fraction $I$ is assumed to occur in the acinar cell. A calcium fraction II, which was independent of protein secretion and pancreozymin stimulation, was demonstrated in concentrations of about 0.4 to $0.6 \mathrm{~m}$-equiv/l. This fraction is thought to originate in the interstitial fluid. The secretion of two calcium-containing fluids is in accordance with the two-component theory of secretion proposed by Hollander and Birnbaum (1952).

The concentration of sodium and potassium in pancreatic juice has been found to lie in the same range as that in the serum under different rates of flow (Johnston and Ball, 1930; Solomon, 1952; Dreiling and Janowitz, 1956); In contrast, it has been known since the investigations of Ball (1930) that the concentration of calcium in pancreatic juice, at 1-2 m-equiv/l, is much lower than in the serum. This suggests that the entrance of calcium into the pancreatic juice is governed by a mechanism which is different from that responsible for sodium and potassium movements.

In human subjects with normal pancreatic function we found a significant increase in calcium concentration and output in duodenal juice following the administration of pancreozymin-cholecystokinin (Goebell, Bode, and Horn, 1970a). This suggested a stimulatory action of this gastrointestinal hormone on the secretion of calcium in the pancreas. To confirm this hypothesis we studied the influence of secretin and pancreozymin-cholecystokinin on the secretion of calcium and enzyme protein in the pure

\footnotetext{
'Present address: Dr H. Goebell, D-79 Ulm/Donau, Zentrumfür Tumere Mediźin, Section of Gastroenterology, University of Ulm, Steinhövelstr. 9.

'Some of the results given in this paper were presented at the 4th World Congress of Gastroenterology, Copenhagen, 1970.

'Supported by grant GO 118/6 from the Deutsche Forschungsgemeinschaft.

Received for publication 29 February 1972.
}

pancreatic juice of dogs, using a permanent duodenal Thomas cannula.

\section{Methods}

Four male mongrel dogs with a mean weight of $25 \mathrm{~kg}$ were equipped under pentobarbital anaesthesia with a permanent duodenal cannula according to the procedure described by Thomas (1959). The accessory ducts were ligated. The animals were allowed to recover for four weeks after operation. The experiments were then carried out once or twice a week. Before beginning the experiments the animals were trained to stand in a harness. Food was withdrawn for 12 hours before each experiment. The investigations were made on the conscious animals (first part of standard experiment), as well as under light anaesthesia with pentobarbital (Nembutal $25 \mathrm{mg} / \mathrm{kg}$ ). The pancreatic juice was collected continuously in five or 10-minute periods in icecooled, 10-ml graduated tubes. The volume of pancreatic flow was stimulated throughout the course of the experiments by a constant infusion of 1 clinical unit of secretin $1 / \mathrm{kg}$ per hour via the femoral vein, the corresponding amount of secretin per hour being dissolved in $30 \mathrm{ml}$ of $0.9 \% \mathrm{NaCl}$. The secreted pancreatic juice was constantly replaced during the experiments by the infusion of an equal volume of $0.9 \%$ saline solution into a femoral vein. In the 'Secretin, Karolinska Institut (Professor Jorpes), Stockholm. 
presence of a secretin-stimulated flow of juice, pancreozymin-cholecystokinin $\left(\mathrm{CCK}^{1}\right)$ was injected intravenously ( 2.5 clinical units per $\mathrm{kg}$ body weight). In some experiments increasing doses of secretin per $\mathrm{kg}$ per hour were infused by means of a motor pump (Perfusor, Braun, Melsungen, Germany).

Sodium, potassium, and calcium were assayed in triplicate in the pancreatic juice by flame photometry (flame photometer Eppendorf, Hamburg). Protein was measured without precipitation, using the biuret method according to Weichselbaum as modified by Beisenherz, Boltze, Bücher, Czok, Garbade, Meyer-Arendt, and Pfleiderer (1953). Turbidity was eliminated by the addition of $\mathrm{KCN}$ to the test tube (Bode, Goebell, and Staehler, 1968). Bicarbonate was measured by titration with $0.01 \mathrm{M}$ $\mathrm{NaOH}$ after the addition of $0.01 \mathrm{M} \mathrm{HCl}$ and boiling (Hodes, 1953); the activity of trypsin was measured spectrophotometrically with N-benzoylarginineethylester (BAEE) (Schwert and Takenaka, 1955). For activation $1 \mathrm{ml}$ of the juice was incubated with

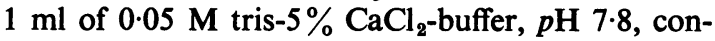
taining $0.05 \mathrm{mg}$ enterokinase in $1 \mathrm{ml}$ for one hour at $25^{\circ} \mathrm{C}$. Lipase was estimated with the $p \mathrm{H}$-stat titration method of Marchis-Mouren, Sarda, and Desnuelle (1959). All measurements of enzyme activities were made at $25^{\circ} \mathrm{C}$.

The BAEE was purchased from Serva Laboratories, Heidelberg, enterokinase from Koch and Light Laboratories, England, all the other chemicals were obtained from Merck, Darmstadt.

'Cecekin, Karolinska Institut, Stockholm.
Results

\section{BASAL SECRETION}

The volume of juice produced under basal conditions varied from 0.2 to $0.5 \mathrm{ml}$ per 10 minutes. The concentration of calcium and protein was high, ie, about 5-6 m-equiv of calcium/l and $30 \mathrm{mg}-40 \mathrm{mg}$ of protein $/ \mathrm{ml}$.

\section{RESPONSE TO SECRETIN INFUSION}

The start of continuous infusion of secretin with 1 clinical unit $/ \mathrm{kg} / \mathrm{hr}$ promptly caused the volume to increase to about $1 \mathrm{ml} /$ minute, as shown in the standard experiment in Figure 1. The concentration of bicarbonate rose to about 120 to $140 \mathrm{~m}$-equiv/l. Concomitantly, the concentrations of calcium and protein fell, together with the enzyme activities (Fig. 2 and Table I). The concentration of calcium was found to lie between 0.6 and $0.8 \mathrm{~m}$-equiv/l. The concentration of protein decreased to a mean value

\begin{tabular}{|c|c|c|c|}
\hline & $\begin{array}{l}\text { Secretin } \\
\text { Infusion } \\
(1 U / k g h r) \\
(n=20)\end{array}$ & $\begin{array}{l}\text { Five Minutes } \\
\text { after Pancreo- } \\
\text { zymin } \\
(n=27)\end{array}$ & $\begin{array}{l}\text { Thirty Minutes } \\
\text { after Pancreo- } \\
\text { zymin } \\
(n=75)\end{array}$ \\
\hline $\begin{array}{l}\text { Protein }(\mathrm{mg} / \mathrm{ml}) \\
\text { Calcium }(\mathrm{m} \text {-equiv/l) } \\
\text { Coefficient of } \\
\text { correlation } \mathbf{r}\end{array}$ & $\begin{array}{l}0.7 \pm 0.32 \\
0.79 \pm 0.13 \\
+0.409\end{array}$ & $\begin{array}{l}23.5 \pm 5.3 \\
2.85 \pm 0.86\end{array}$ & $\begin{array}{l}11.5 \pm 10.2 \\
1.82 \pm 1.0 \\
+0.826\end{array}$ \\
\hline
\end{tabular}

Table I Concentrations of protein and of calcium in pancreatic juice of dogs after infusion of secretin and superimposed stimulation with pancreozymincholecystokinin

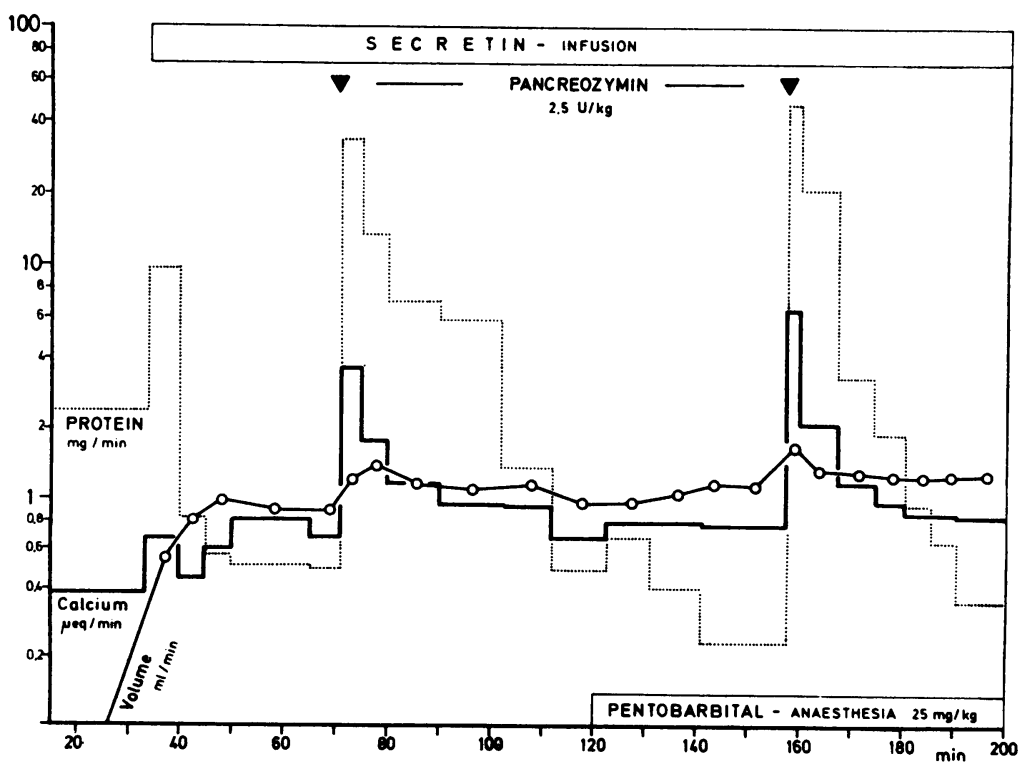

Fig. 1 Standard experiment. Effect of a double stimulation with pancreozymin on the output of protein and calcium in pancreatic juice of a dog. 


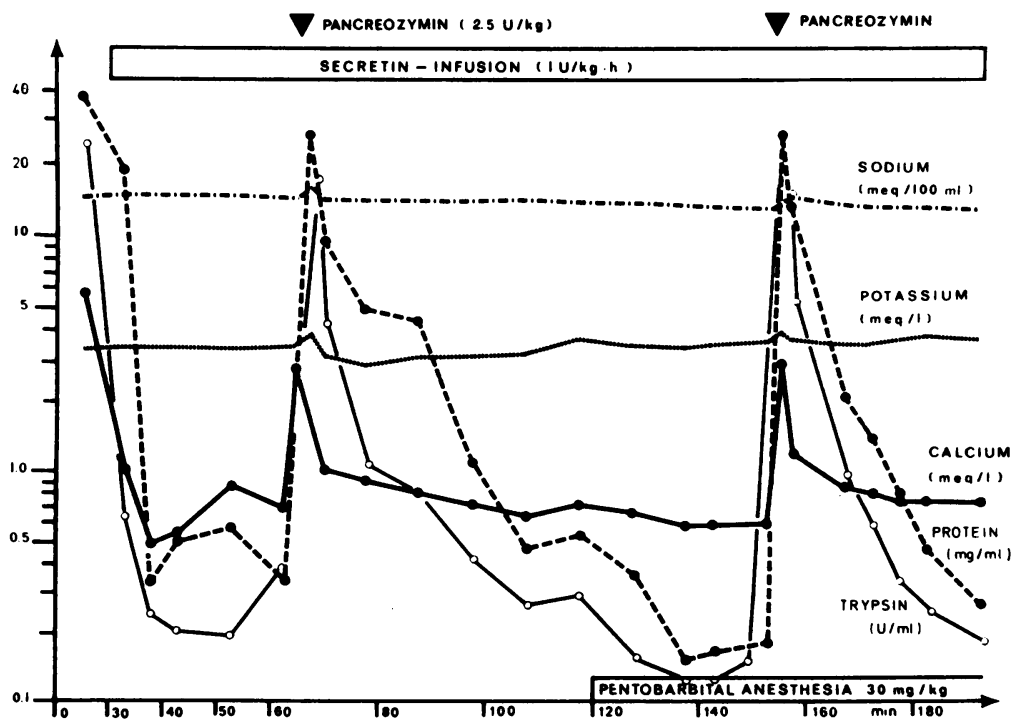

Fig. 2 Concentrations of calcium, protein, trypsin, sodium, and potassium in pancreatic juice of a dog, stimulated twice by injections of pancreozymin. In the second part of this standard experiment anaesthesia was induced with pentobarbital.

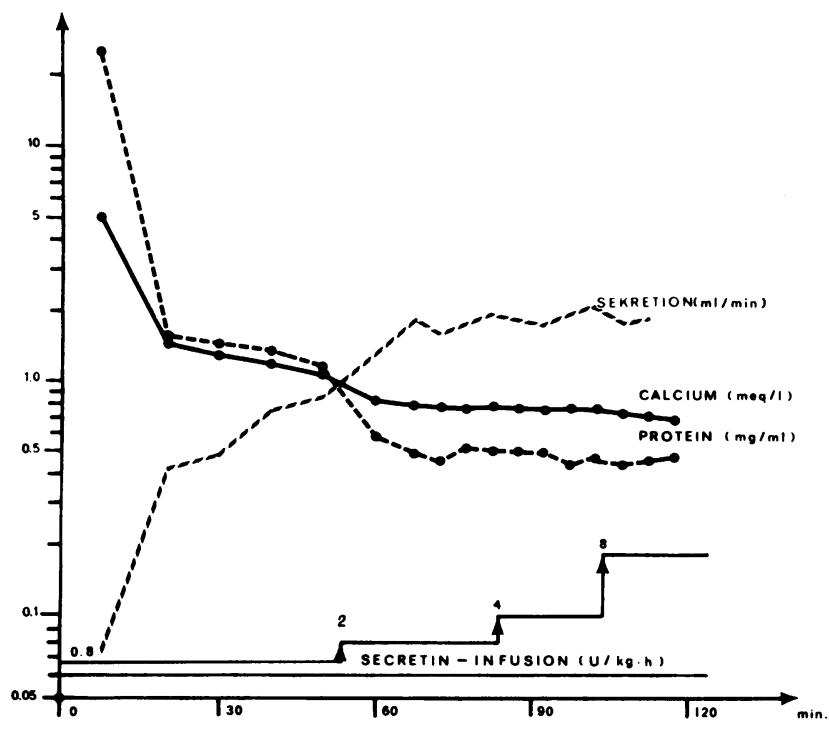

Fig. 3 Effect of secretin infusion with different doses on the volume and the concentration of calcium and protein in pancreatic juice of a dog. Anaesthesia with pentobarbital.

of $0.7 \pm 0.32 \mathrm{mg} / \mathrm{ml}$. During the transition from the conscious state to pentobarbital-induced sleep the protein concentration was observed to fall to about $0 \cdot 1-0.2 \mathrm{mg} / \mathrm{ml}$, without variation in the calcium concentration (Fig. 2). Figure 3 gives an example of the influence of a stepwise increase in the dosage of infused secretin on flow rate and on calcium and protein concentration in the juice. The volume produced reached a plateau at 2 clinical units $/ \mathrm{kg} / \mathrm{hr}$. Calcium and protein concentrations in the juice were found to decrease, and then to remain stable at relatively low values after about half an hour of infusion of 2 units $/ \mathrm{kg} / \mathrm{hr}$ of secretin. The concentrations of sodium and potassium were found in the range of serum values and were not influenced significantly by secretin infusion.

\section{STIMULATION WITH PANCREOZYMIN-} CHOLECYSTOKININ

As shown in the standard experiment of Fig. 2 , the injection of $2 \cdot 5$ units $/ \mathrm{kg}$ pancreozymincholecystokinin (CCK) induced a sharp increase in the concentrations of both calcium and protein. The activities of trypsin and lipase were strictly pro- 
portional to the protein concentration. The basal levels were reached again during the following $\mathbf{5 0}$ minutes. A second stimulation with a similar dose of CCK 90 minutes later under pentobarbital anaesthesia was promptly followed by another parallel increase in calcium and enzyme protein concentration. The mean values of all experiments for the first five and the first $\mathbf{3 0}$ minutes after stimulation with CCK are given in Table I. Figure 1 shows that the total output of calcium and protein is increased by the injection of CCK in the same manner as the concentration, indicating a genuine stimulation of both protein and calcium secretion. The concentrations of sodium and potassium showed no significant alteration after pancreozymin-cholecystokinin.

\section{SHORT INTERVAL KINETICS OF CALCIUM AND PROTEIN SECRETION AFTER CCK}

The kinetics of the behaviour of calcium and protein in the juice were studied in an experiment over brief intervals, results of which are given in Figure 4. The juice was collected after the injection of CCK in 30-60-second periods. Immediately after the injection of CCK, which was accomplished within 15 seconds, the concentrations of calcium and of protein rose sharply. The peak concentration was reached in the second minute with $4.95 \mathrm{~m}$-equiv/l for calcium and $32 \mathrm{mg} / \mathrm{ml}$ for protein. From the third minute both concentrations fell continuously. The decline of the two curves does not seem to be parallel. A correction must be made for the preexisting basal levels of both concentrations. In the two lower curves of Fig. 4 the real increment and decline of protein and calcium concentration evoked by CCK is calculated. It now becomes evident that the calcium concentration in all phases of the experiment runs parallel to the concentration of enzyme protein.

\section{STATISTICAL RELATIONSHIP BETWEEN}

CALCIUM AND PROTEIN SECRETION

The coefficient of correlation between the con-

\begin{tabular}{|c|c|}
\hline & Coefficient of Correlation $r$ \\
\hline $\begin{array}{l}\text { Infusion of secretin } \\
(1 \mathrm{U} / \mathrm{kg} \mathrm{hr})\end{array}$ & $\begin{array}{l}-0.504{ }^{(4)^{1}} \\
-0.477(4) \\
+0.456 \\
+0.963 \\
+0.276 \\
+(3) \\
\end{array}$ \\
\hline $\begin{array}{l}\text { Infusion of secretin }+ \text { injection } \\
\text { of pancreozymin }(2.5 \mathrm{U} / \mathrm{kg})\end{array}$ & 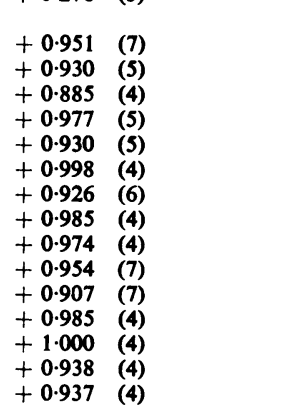 \\
\hline $\bar{x} \pm s$ of $r$ after pancreozymin & $+0.952 \pm 0.031$ \\
\hline
\end{tabular}

Table II Correlation between concentration of calcium (m-equiv/l) and of protein $(\mathrm{mg} / \mathrm{ml})$ in pancreatic juice from seven experiments with 15 stimulations with pancreozymin

${ }^{1}$ The number of paired values for each stimulation.

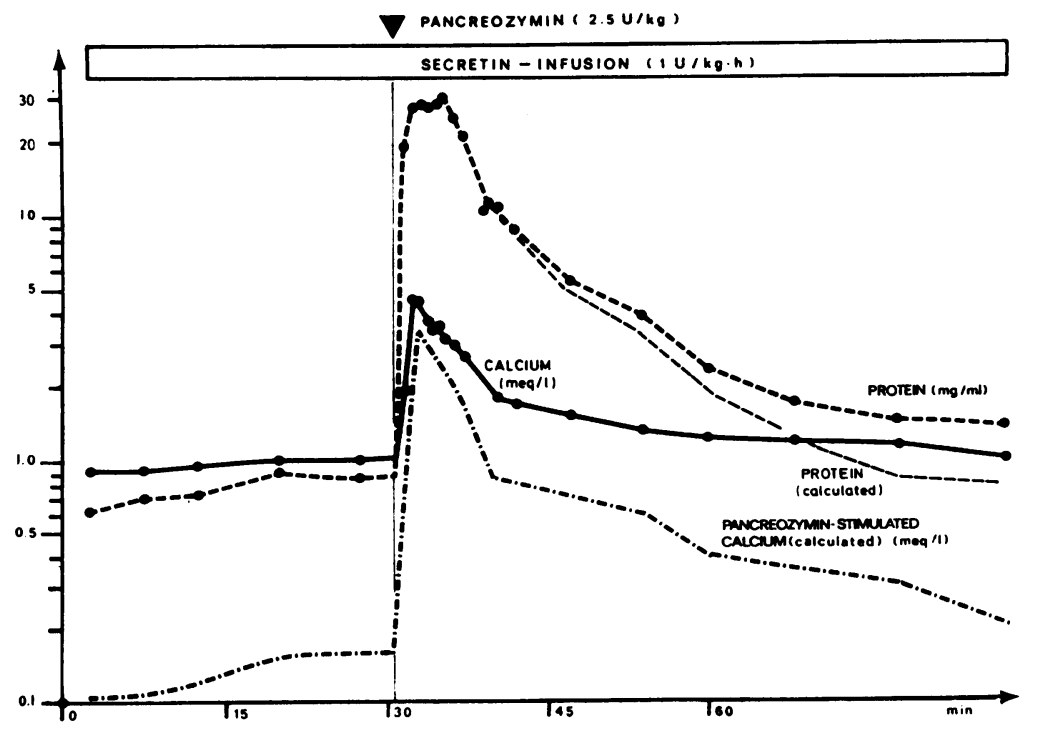

Fig. 4 Short-interval kinetics of the concentration of calcium and protein in pancreatic juice of a dog after stimulation with pancreozymin. The juice was collected in fractions of 30 and 60 seconds' duration after the injection of CCK. Anaesthesia with pentobarbital. 
centrations of calcium and protein for all experiments is given in Table II. Both parameters were positively correlated after the injection of CCK with $r=+$ $0.952 \pm 0.031$. In contrast, no correlation could be detected in the secretin-stimulated juice. In this juice the ratio of calcium to protein computed from the values given in Table I was found to be $0.7 \mu$-equiv of calcium $/ 1 \mathrm{mg}$ of protein. The mean increase in the secretion of calcium after the injection of CCK was about $0.1 \mu$-equiv of calcium for each milligram of protein.

\section{Discussion}

Values for the concentration of calcium in the pure pancreatic juice of dogs have been given by Ball (1930), Johnston and Ball (1930), Komarov, Langstroth, and McRae (1939), Solomon (1952), McPherson, and Pace (1961), Herskovic, Wakim, Bartholomew, Cain, and Jones (1965), Zimmerman, Dreiling, Rosenberg, and Janowitz (1967). Most observations were made on the basal secretion, or after stimulation with secretin itself or of the secretin mechanism by instillation of hydrochloric acid into the duodenum. The basal concentration of calcium is usually found in the range between 2 and 5 m-equiv/l, with wide variations. Stimulation with secretin leads to a high output of volume and an increase in bicarbonate concentration, with a concomitant decrease in calcium concentration (Herskovic et al, 1965; Zimmerman et al, 1967). This has been confirmed in our experiments with constant infusion of secretin. The concentration of protein decreased regularly after secretin, but no statistical correlation between protein and calcium could be found in the secretin-stimulated juice.

Pancreozymin-cholecystokinin induced a significant increase in concentration and output of calcium, positively correlated with protein and enzyme secretion. The peak concentration was found in the second minute following injection of pancreozymin. At a level of approximately $5 \mathrm{~m}$-equiv/l it exceeded the concentration of the ionized fraction of calcium in the serum (Oreskes, Hirsch, Douglas, and Kupfer, 1968; Fuchs and Paschen, 1971). The secretion of calcium and amylase after a combined injection of secretin and pancreozymin was studied by Zimmerman et al (1967), who found higher concentrations of calcium than after secretin alone. They concluded from these findings that the secretion of calcium might be associated with that of the enzymes. Our experiments provide clear evidence that the entrance of a calcium fraction I into the juice has a very close connexion with enzymes and is regulated by pancreozymin-cholecystokinin. This mechanism was proposed by us in studies on calcium and pancreatic enzymes in duodenal juice of human subjects with normal pancreatic function (Goebell et al, 1970a) and with primary hyperparathyroidism (Goebell, Horn, Bode, and Gossmann, 1970b). In secretin-stimulated juice $1 \mathrm{mg}$ of protein was found to correspond to $0.7 \mu$-equiv of calcium. On the other hand, the pancreozymin-stimulated increase in calcium concentration was $0.1 \mu$-equiv per $1 \mathrm{mg}$ of protein. This difference shows that, in addition to that bound to protein, some calcium must also enter the juice by another mechanism. This protein -independent calcium fraction II was found under conditions of maximum flow rates to amount to 0.4-0.6 m-equiv/l. It was distinctively evident in the experiment graphed in Fig. 2, in which the concentration of protein in the juice after the start of anaesthesia was decreased to $0.15 \mathrm{mg} / \mathrm{ml}$. The calcium concentration during the same period remained constant at $0.6 \mathrm{~m}$-equiv/l. According to the relationship postulated above between protein and calcium in the secretin-stimulated juice, $0.15 \mathrm{mg}$ of protein corresponds to $0.11 \mu$-equiv of calcium. The protein-independent fraction in this case therefore is 0.6 minus $0.11=0.49 \mathrm{~m}$-equiv $/ 1$.

Theoretically, according to the findings in gastric juice, we must assume the entrance of four calcium fractions into the pancreatic juice (Moore and Makhlouf, 1968): (1) ionized calcium by diffusion from the interstitial spaces; (2) solubilized calcium complexes by diffusion from the interstitial spaces; (3) calcium originally bound to albumin entering the juice from the interstitium; and (4) calcium which enters the juice bound to enzyme protein from the acinar cells under the influence of pancreozymin.

According to Clemente, Ribeiro, Figarella, and Sarles (1971), in the normal pancreas about $0.2 \mathrm{mg}$ of albumin is found in $1 \mathrm{ml}$ of juice. If $0.02 \mathrm{~m}$ mole of calcium is bound to each gram of protein (Moore, 1967), this amount of albumin would account for $0.004 \mu$-equiv of calcium per $\mathrm{ml}$ of juice. This could be neglected in the normal pancreas but might play a role in the chronically inflamed gland, in which higher amounts of albumin have been found to reach the pancreatic juice (Clemente et al, 1971). Moore et al (1968) have estimated the concentration of total ionized and complex-bound calcium in the interstitial fluid as 1.57 m-equiv/l. This would favour diffusion into pancreatic juice via a concentration gradient.

Under the influence of pancreozymin-cholecystokinin calcium reaches the juice together with enzyme protein from the acinar cells. Moore et al (1968) have shown that calcium enters the gastric juice from the chief cells in the stomach bound to pepsinogen. The secretion of calcium was increased, together with that of pepsinogen, after the administration of 
histamine and gastrin II. One $\mathrm{mg}$ of protein was correlated with $0 \cdot 2-0 \cdot 3 \mu$-equiv of calcium. Although this level is somewhat higher than that in pancreatic juice, it is of the same order of magnitude. Out of 15 possible binding places for calcium in the pepsinogen molecule, $14 \cdot 1$ were found to be occupied (Moore et al, 1968). This suggests that all the calcium is bound to enzyme protein when it is released from the enzyme-secreting cells. In the further course of the flow through the gland a new balance between ionized and protein-bound calcium is established, depending on the $p \mathrm{H}$. Some preliminary data on the ionized calcium in the pancreatic juice of dogs have recently been given by Zimmerman, Moore, Dreiling, and Janowitz (1971). The level ranged between 0.39 and $1.22 \mathrm{~m}$-equiv/l in the basal secretion and fell to $0.075 \mathrm{~m}$-equiv/1 after single intravenous doses of secretin 5 units $/ \mathrm{kg}$.

The entrance of two main calcium fractions into the pancreatic juice, ie, one from the acinar cells and the other from interstitial spaces, is in accordance with the two-component theory of Hollander and Birnbaum (1952). The final concentration of calcium in the juice would then be the result of the admixture of two juices with different calcium concentrations. The exchange theory of Janowitz and Dreiling (1962) considers calcium to be secreted in a primary juice, in a concentration in the range of the ionized calcium fraction in the serum. Reabsorption of calcium would then account for the low concentrations in the secretin-stimulated juice. After stimulation with pancreozymin most of the calcium would reach the duodenum bound to the enzyme protein. Our finding that the calcium concentration in pancreatic juice reaches values well above the concentration of the ionized calcium in serum is opposed to the exchange theory and in favour of the admixture theory.

\section{References}

Ball, E. G. (1930). The composition of pancreatic juice and blood serum as influenced by the injection of inorganic salts. J. biol. Chem., 86, 449-462.

Beisenherz, G., Boltze, H. J., Bücher, Th., Czok, R., Garbade, K. H., Meyer-Arendt, E., and Pfleiderer, G. (1963). Diphosphoglyceraldehyd-Dehydrogenase, Milchsäure-Dehydrogenase, Glycerophosphat-Dehydrogenase und Pyruvatkinase aus Kaninchenmuskulatur in einem Arbeitsgang. Z. Naturforsch., 8b, 555-577.
Bode, C., Goebell, H., and Stähler, E. (1968). Zur Eliminierung von Trübungsfehlern bei der Eiweißbestimmung mit der Biuretmethode. Z. klin. Chem. 6, 418-422.

Clemente, F., Ribeiro, T., Figarella, C., and Sarles, H. (1971). Proteines sériques dans la sécretion pancréatique (Abstr.) In Vth Symposium European Pancreatic Club, Brussels, 1971, p. 9.

Dreiling, D. A., and Janowitz, H. D. (1956). The secretion of electrolytes by the human pancreas. Gastroenterology, 30, 382-390.

Fuchs, C., and Paschen, K. (1972). Die Bestimmung des ionisierten Calciums im Serum mit Hilfe einer ionen-selektiven Elektrode. Dtsch. med. Wschr., 97, 23-24.

Goebell, H., Bode, C., and Horn, H. D. (1970a). Einfluß von Sekretin und Pankreozymin auf die Calciumsekretion im menschlichen Duodenalsaft bei normaler und gestörter Pankreasfunktion. Klin. Wschr., 48, 1330-1339.

Goebell, H., Horn, H. D., Bode, C., and Gossmann, H. H. (1970b). Primärer Hyperparathyreoidismus und exokrine Pankreasfunktion. Klin. Wschr., 48, 810-819.

Herskovic, T., Wakim, K. G., Bartholomew, L. G., Cain, J. C., and Jones, J. D. (1965). Relationship of calcium in the serum to that in the pancreatic secretion in normal and hypercalcemic states. Surgery, 58, 530-534.

Hodes, M. E. (1953). Carbon dioxyde content (titrimetric). In Standard Methods of Clinical Chemistry, edited by M. Reiner, Vol. 1, pp. 19-22. Academic Press, New York.

Hollander, F., and Birnbaum, D. (1952). The role of carbonicanhydrase in pancreatic secretion. Trans. N.Y. Acad. Sci., 15, 56-58.

Janowitz, H. D., and Dreiling, D. A. (1962). The pancreatic secretion of fluid and electrolytes. In Ciba Foundation Symposium on the Exocrine Pancreas, edited by A. V. S. de Reuck and M. P. Cameron, pp. 115-137. Churchill, London.

Johnston, C. G., and Ball, E. G. (1930). Variations in inorganic constituents of the pancreatic juice during constant drainage of the pancreatic ducts. J. biol. Chem., 86, 643-653.

Komarov, S. A., Langstroth, G. O., and McRae, D. R. (1939). The secretion of crystalloids and protein material by the pancreas in response to secretin administration. Canad. J. Res., D., 17, 113 123.

McPherson, R. C., and Pace, W. G. (1961). Calcium excretion by the pancreas in hypercalcemia. Surg. Forum, 12, 372-374.

Marchis-Mouren, G., Sarda, L., and Desnuelle, P. (1959). Purification of hog pancreatic lipase. Arch. Biochem., 83, 309-319.

Moore, E. W. (1967). Ionized calcium directly determined by ionexchange electrodes: the state of serum calcium in patients with cirrhosis (Abstr.). J. clin. Invest., 46, 1097.

Moore, E. W., and Makhlouf, G. M. (1968). Calcium in normal human gastric juice. Gastroenterology, 55, 465-480.

Oreskes, I., Hirsch, C., Douglas, K. S., and Kupfer, S. (1968). Measurement of ionized calcium in human plasma with a calcium selective electrode. Clin. chim. Acta., 21, 303-313.

Schwert, G. W., and Takenaka, Y. (1955). A spectrophotometric determination of trypsin and chymotrypsin. Biochim. biophys. Acta (Amst.), 16, 570-575.

Solomon, A. K. (1952). Symposium on secretion of electrolytes: Electrolyte secretion in the pancreas. Fed. Proc., 11, 722-731.

Thomas, J. E. (1959). Symposium: exocrine pancreatic function; methods for collecting pancreatic juice. Gastroenterology, 36, 362-367.

Zimmerman, M. J., Dreiling, D. A., Rosenberg, I. R., and Janowitz, H. D. (1967). Secretion of calcium by the canine pancreas. Gastroenterology, 52, 865-870.

Zimmerman, M. J., Moore, E. W., Dreiling, D. A., and Janowitz, H. D. (1971). Pancreatic juice ionized and total caleium in dogs in response to secretin, pancreozymin, and calcium infusions. (Abstr.) J. clin. Invest., 50, 103a. 